هى : التشريح والهستولوجيا والتوليد ــكلية الطب البيطرى- جامعة أسنيوط.

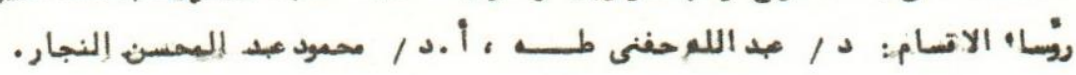

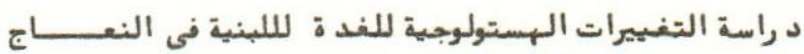

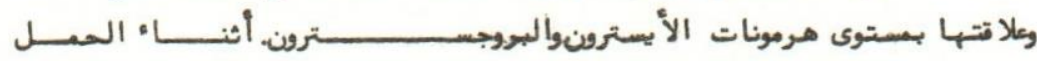

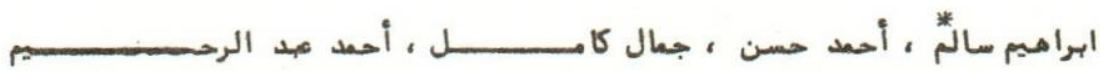

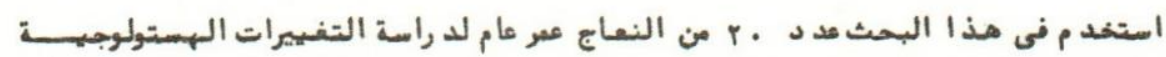

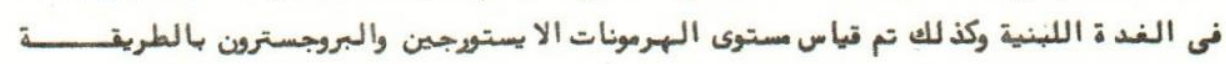

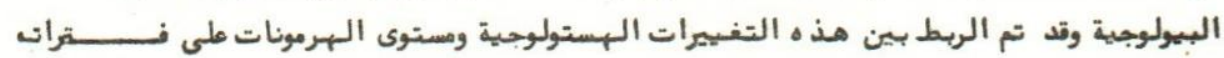

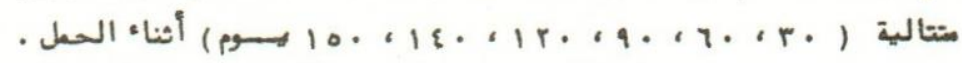


Depts. of Animal Production, Anatomy \& Histology and Gynaceology,

Faculty of Agriculture and Vet. Med., Assiut University,

Head of Dept. Prof. Dr. H. El-hammady, Dr. A. Hifny \& Prof. Dr. H. Osman.

\title{
HISTOLOGICAL CHANGES IN THE MAMMARY GLAND OF EWE IN RELATION TO ESTROGEN AND PROGESTERONE LEVELS DURING PREGNANCY
}

(With 2 Tables and 10 Figures)

By

1. SALEM: A.H.S. HASSAN: G, KAMEL and A.A. ABDEL-RAHEIM

(Received at 2/4/1982)

\section{SUMMARY}

\begin{abstract}
The changes in the proportion of glandular tissue, alveolar diameter, number of alveoli per unite area, number of nucleiper alveolar cross section and the stromal area were estimated quantitatively in the mammary gland in relation to oestrogen and progesterone levels in ewe slaughtered at frequent intervals of pregnancy $(30,60,90,120$ and 140 days) as well as immedlatley before parturation.

The proportion of the glandular tissue increased gradually from $9 \%$ at day 30 and reached 848 at day 150 of pregnancy.

There was a stricking fall in the number of alveoll per unfte area and a corresponding rise in the alveolar diameter from day 120 of pregnancy till before lambing.

The number of nuclel in the average alveolar cross section was relatively constant until day 90 then gradually increased and reached. Its maximal value on day 150.
\end{abstract}

\section{INTRODUCTION}

Investigations describing the qualftative changes in the mammary gland during the lactational cycle (pregnancy, lactation and involution) have been carried out by several authors (TURNER, 1934,1935; KONG, 1940; WEBER et al, 1955 and PRUSTY, 1958) in cow, (NOSEIR, 1974, El-SHEIKH and SULTAN, 1977) in buffalo, (NOSEIR, 1973)in camel, (TURNER and REINEX, 1963/SCHMIDT et al, 1962), in goat (KURESUMI et al, 1968) in rat.

More detalled quantitative studies have been reported in rat and cow (ALTMAN, 1945), goat (NAITO et al, 1968), rat and mice (MUMORD, 1963). However, the histological structure of the mammary gland in relation to the levels of oestrogen and progesterone hormones in ewe during pregnancy were not encountered in the available 1iterature.

The aim of the present work is to correlate the histological changes concerning the proportions of the glandular tissue, the number of alveoli per unit area, the diameter of milk alveoli and the number of nuclei per alveolar cross section in the mammary gland with the alterations in the levels of oestrogen and progesterone in fat-tailed ewe during pregnancy.

\section{MATERIAL and METHODS}

Twenty one yearling virgin fat-tailed ewe were used in the present experiment. These ewes were maintained on pastuee at the animal research station, Faculty of Agriculture, Assiut University. The determination of onset pf estrus was by means of a marker ram. The ewe in estrus were bred by this ram. Three ewes slaughtered at each of the following time intervals, 30, 60, 20, 120, 140 days of pregnancy and immediately before parturition. The udder was separated immediately after slaughtering, weighted and 3 specimens from each gland were cut, $\mathrm{flxed}$ in Bouin's fluid, dehydrated, cleared, embedded in paraffin and sectioned at 6 microns thicknes and every tenth section retained. The sections were stained with homatoxylin and eosin and Mallory trichrome stains.

\section{HISTOMETRIC MEASUREMENTS}

Proportion of glandular tissue:

It was estimated from measurements on 25 areas selected at random from 5 sections of each specimen. The selected sections of each slide were profected at a magniflcation of 120 times and the outline of the glandular 
tissue traced and the area measured with the aid of the planimeter.

Number of alveoli per unite area:

It was calculated at magnification 120 , the actual area was $0.884667 \mathrm{~mm}^{2}$.

Number of nuclel per alveolar section:

Random eross sections of milk alveoll were selectod and the number of nuclei were counted.

The diameter of alveolar section:

It was estimated by using an occular micrometer which was calj.brated with a stage micrometer to the nearest micron. Statistical analysis was carried out according to Sendecor (1956).

Oestrogen and progesterone hormones were determined according to SZECO and ROBERTS (1947).

\section{RESULTS}

The present study revealed that the mammary gland of nonpregnant ewe contain no secretory or alvolar tissue in this stage. The ductules are situated in groups between the fat tissue (Fig. 1).

The quantitative morphological changes in the mamnary glands of ewe during pregnancy are shown in Table(1) and (Fig. 9).

The mammary gland of ewe after 30 days of pregnancy had little glandular tissue (9\%) represented by ductules and few alveoli ( 40 per unit area). The milk alveoli ( $F 1 \mathrm{~g} .2$ ) was either without or with a small lumen and consisted mainly of clumped columnar cells with pale basophille cytoplasm and large spherical besicular nucle1. Their average number per alveolar cross section was about 13. These columnar cells were surrounded by interrupted layer of myoeplthelial cells. The intralobular duct (Fig. 3) was formed of two cell layers, the Inner layer facing the lumen was formed columnar cells with large, ioval, lightly stained nuelei and aeidophilic cytoplasm. The basal one appeared cuboidal with spherical or irregular nuclel. The intralobular C.T. are highly cellular contain abundant plasma cells (Fig. 4). The stromal area was abundant and rich in adipose tissue.

After 60 days of pregnancy, there were slight increase in the proportion of the glandular tissue (21\%), and the number of alveoli per unit area (63) as well as a slight reduction in the stromal area (79\%). At the same time there was no sifniciant difference in the alveolar diameter and the number of per albeolar cross sections. The lumen of the milk alveoli are still narrow and do not contain any secretory material.

As the pregnancy advanced (90-120 day) the mamanary gland showed increased milk secreting units (Fig. 5, 6) with a reduction in the number of intralobular non functioning parenchymatous ductules. The epithelium of the ductules still appears twolayered with a basement membrane. The number of milk alveoli at this time (90-120 days of pregnancy) was 154 and 180 per unit area respectively. The secretory segments were lined with high chboidal cells, containing IIghtly stained nuclei. Their cytoplasm was pale basophillc and pinely vacuolated. The luminal area become wider than the that in the previous stages.

In a late stage of pregnancy ( $140 \mathrm{day}$ ) and Immediately before parturition (150 day), all the lobules of the matmary gland were formed of secretory alveoll and few intralobular parenchymatous tubules (Fig. 7). The stromal area were greatly reduced (16\%). The nilk alveoll were lined with cuboidal cells and have a widely distended lumen qhich was filled with acidophilic secretion. The epithellal cells of the milk alveoli showed a marked secretory activity, indicated by the presence of large vacuoles at the free border of these cells (Fig. 8). At these stages there were a stricking fall in the number of alveoli per unit area and corresponding rise in the alveolar diameter. These changes were positively correlated with the luminal area. The number of niolel in the average alveolar cross section reached its maximal value before parturition (Table 1 and Fig. 9).

The oestrogen level during pregnancy was low unitl the day 90 , then rose to the mean peak at the day of parturition (Fig. 10). 
The serum value of progesterone rose in pregnant ewe to $294 \mathrm{ug} / \mathrm{Lit}$. at day 120, then a steep fall to $91 \mathrm{ug} /$ Lit. was recorded at the day of almbing ( $F 1 g .10$ ).

\section{DISCUSSION}

The present study revealed that the proportion of the glandular tissue of the mamnary gland of ewe increased gradually from day 30 of pregnancy $(9 \%)$ to reach its maximal value (84\%) immediately before parturition.

The number of nuclei in the average alveolar cross section of the mamary gland of ewe was relatively constant until 90 days of pregnancy, then gradually increased, reaching its maximal value before parturition. A similar increase in the number of nuclei per alveolar cross section occurred about the time of parturition in cow (HOWE et al, 1977; ALTMAN, 1945), goat (NAITO et al, 1955), guinea pig (NAITO, 1958) and in rat and mice MUNFORD, 1963).

In the mamnary gland of ewe the marked increase in the alveolar diameter and corresponding decrease in the number of alveoli per unit area at the late stage of pregnancy and immediately before parturition reflect the onset of copious secretion and distintion of milk alveoli. This view support the finding of NAITO et al, (1955) in guinea pig of early stages of lactation.

In late pregnancy (140 day) and immediately before parturition (150 day) all the lobule of the mammary gland of ewe are mainly formed of secretory alveoli and few intralobular tubule. This indicate that the two cell layered parenchymatous tubules observed until 90 of pregnancy are completely transformed into milk alveoll. This observation are in agreement with MOUSSA (1977) in buffaloe.

In agreement with MRX and COLE (2965), the plasma cells were seen in the mamary gland of ewe during pregnancy. These cells may be the source of gamma globulin in the colostrum.

The correlation between the histological changes in the mammary gland of ewe during pregnancy and the level of oestrogen and progesterone hormones indicated that, growth of the mammary gland in ewe occur as a result of synergistic action of these hormones. This view could be assumed that the higher level of oestrogen act upon the lactiferous ducts and stimulating their growth by increasing the number of mitoses, causing 1 ts ramification. Moreover, the increased value of progesterone may stimulate the gorwth of the secretory part of the mammary gland. These pindings are greatly supported by the results of CATCHPOLE (1977) and CARROLL. (1980) in sheep.

\section{REFERENCES}

Altman; A.D. (1945): Udder changes in lactating cow. Vestn zhivotnov. 1: 85.

Corroll, E.J., (1980): Lactation, In: Veterinary endocrinology and reproduction. SEd. L.E. McDonald), Lea and Febiger, Philadelphia.

Catchpole, H.R., (1977): Hormonal mechanism in pregnancy and parturation. In: Reproduction in domestic animals. (Ed. H.H. Cole and P.T. Cupps), Academic Press, New York. San Francisco. London.

El-Shelkh; A.S. and Sultan. Z.A. (1977): Developmental changes in the udder secretory tissue of the Egyptlan buffaloe. Indian J. Anim. Sc1. 47 (10).

Harkness, M.L.R., \& R.D. Harlness (1956): The effect of pregnancy and lactation on the collagen content of the rat. J. PHyslology. $132: 476$.

Howe, L.E., Helad. C.W. \& Bibb. T.L. (1975); Histology of induced Bovine Lactogenesis. J. Dairy Sci., $28,6$.

Kong, F.J. (1940): A histological sutcly of the mammary gland of the cow during pregnancy. 3. Am. Vet. Ass., 96, $36-40$.

Kurosumi, K.; Kobayashi, Y. and Baba; N. (1968): The Plne structure of mamnary glands of lactating rats with special reference to the apocrine secretion. Exp. Cell. Res. 50, 177-192.

Marx, G.D. \& Cole, C.L. (1965): Histological study of the mamary gland to determine origin of specific gamma globulin secretion in milk. Dairy Sc. 48 (6) 801 .

Assiat.Vet.Med.J.Yol. 11, No. 21, 1983. 


\section{SALEM, et al.}

Moussa, M.H.G. (1977): Some micro-morphological studies of the udder of the buffalo in Egypt. M.V.Sc. Thesls. Faculty of Vet. Med. Calro University.

Munford, R.E. (1963 a): Changes in the mammary glands of rats and mice during pregnancy, Lactation and involution. 1- Histological structure. J. Endocrinol. 28. 1.

Munford, R.E. (1963 b): Changes in the mamnary glands of rats and mice during pregnancy, Lactation and involution. 3- Relation of structural and biochenical changes. J. Endocrinol. 28. 35.

Naito, M. (1958): Histological changes in the mamnary gland of guinea pigs during lactation. J. Dairy Res. 25, 395.

Naito, M., Shoda, Y. and Nagai, J. (1955): Relation between dairy performance and mammary structure in dalry goats. Endocr. Jap. 2.205.

Noselr, M.B. (1973): Histological structure of the mamnary glands of the one-humped camel (camelus dromedrus). Indian. J. Antmal Sel. 43, 639-641.

Noseir, M.B., Zaki, K.M.; Shalash. M.R. arid Aflefy, H.M. (1974): Histological assessment of buffalo's mammary gland development. Vet. Med. J., Faculty of Vet. Med., Cairo University, 22, 25-34.

Prusty, J.N. (1958): Distribution of the elastle tissue in the mammary gland of cow. Brit. Vet. J. $114,411$.

Schmidt, G.H.; Chatterton, J.R.T. and Hansel, W. (1962); HIstological changes during involution of the mammary glands of ovariectomized and intact lactating goat. J. Dairy Sc., 45, 1380.

Snedecor, G.W., and W.G. Cochran (1967): Statistical methods, 6th ed., Iowa State Uni. Press Iowa, U.S.A. Szigo, C.M., \& S. Roberts, (1247): C1ted by Sald, A.H., and F.A. Soliman, (1965) Naure, Vol.205, No. 4971, P.605. Turner, C.W. (1934): The cause of the growth and function of the udder of cattle. Mo. Ag. Exp. Sta, Res. Bul, 339.

Turner, C.W. (1935): The structure of the cows udder. Mo. Ag. Exp. Sta. Res. Bul. 344.

Turner, C.W. and Reinex, E.P. (1936): A study of the Involution of the mammary gland of the goat. Mo. Ag. Exp. Sta. Res. Bul., 235.

Weber; A.F., Kitchell, R.L. \& Sautter, J.H. (1955): Mamnary gland studies. I. The identity and characterization of the smallest lobule unite in the udder of the dairy cow. Am. J. Vet. Res. 16, 255. 
MAMMARY GLAND OF ELWE

Table 1: Quantitative morphological changes in the mammary gland of ewe during pregnancy.

\begin{tabular}{|c|c|c|c|c|c|c|c|c|c|c|}
\hline & 30 day & 60 day & \multicolumn{2}{|c|}{90 day } & \multicolumn{2}{|c|}{$120 \mathrm{day}$} & \multicolumn{2}{|c|}{140 day } & \multicolumn{2}{|c|}{150 day } \\
\hline & Mean SD & Mean & Mean & SD & Mean & SD & Mean & SD & Mean & SD \\
\hline $\begin{array}{l}\text { Proportion of glandular } \\
\text { ti ssue (q) }\end{array}$ & $9.0 \pm 1.8$ & $21.0 \pm 4.4$ & 49.0 & \pm 4.5 & 63.0 & \pm 63 & 75.0 & \pm 5.1 & 84.0 & $\pm 7,73$ \\
\hline Stromal area $(z)$ & $91 \pm 1.8$ & $79 \pm 4.4$ & 51 & \pm 4.5 & 37 & \pm 6.2 & 25 & \pm 5.1 & 16 & \pm 8.5 \\
\hline $\begin{array}{l}\text { Number of alveoli per } \\
\text { unite area. }\end{array}$ & $40 \pm 6.27$ & $63 \pm 9.7$ & 154 & \pm 15.6 & 180 & \pm 18.7 & 76 & \pm 17.0 & 53 & \pm 14.8 \\
\hline $\begin{array}{l}\text { Number of nuclei per } \\
\text { alveolar section }\end{array}$ & $13 \pm 2.03$ & $13 \pm 1.90$ & 16 & \pm 296 & 23 & \pm 4.19 & 33 & \pm 425 & 35 & +7.4 \\
\hline Alvolar diameter (U) & $30.8 \pm 8.31$ & $39.5 \pm 8.87$ & 41.5 & $5 \pm 8.25$ & 49.6 & \pm 7.25 & 100 & \pm 21 & 135 & \pm 15.5 \\
\hline
\end{tabular}

Table 2 : Analyses of Variance of changes during pregnancy for measurements on the mammary 8 land of ewe.

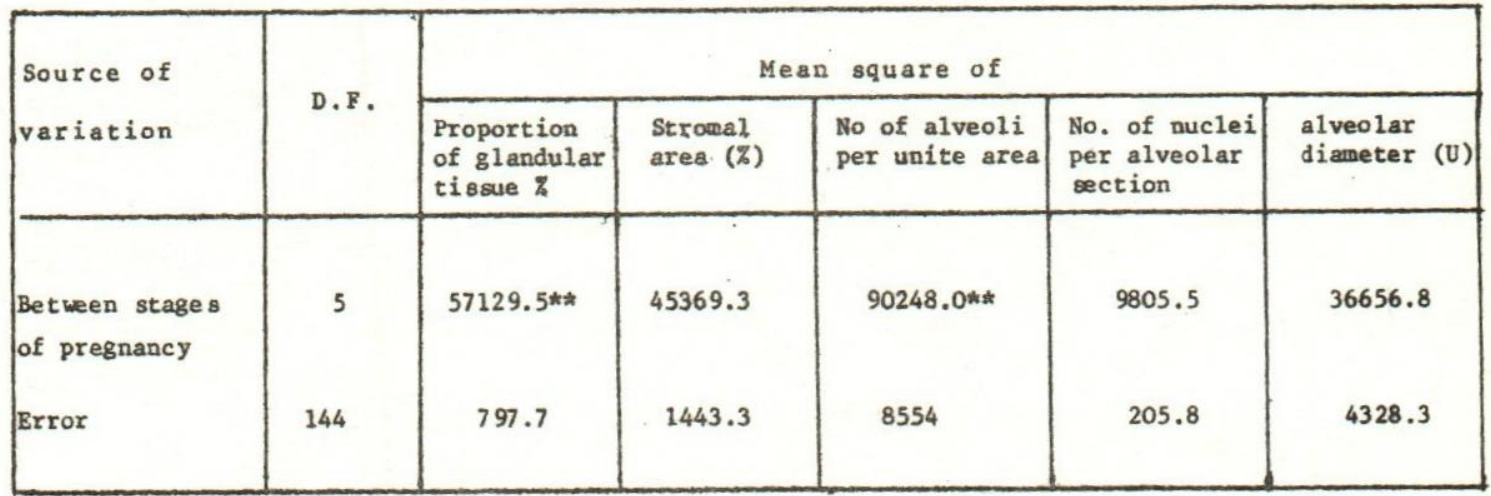

** Significant at $P<0.01$. 


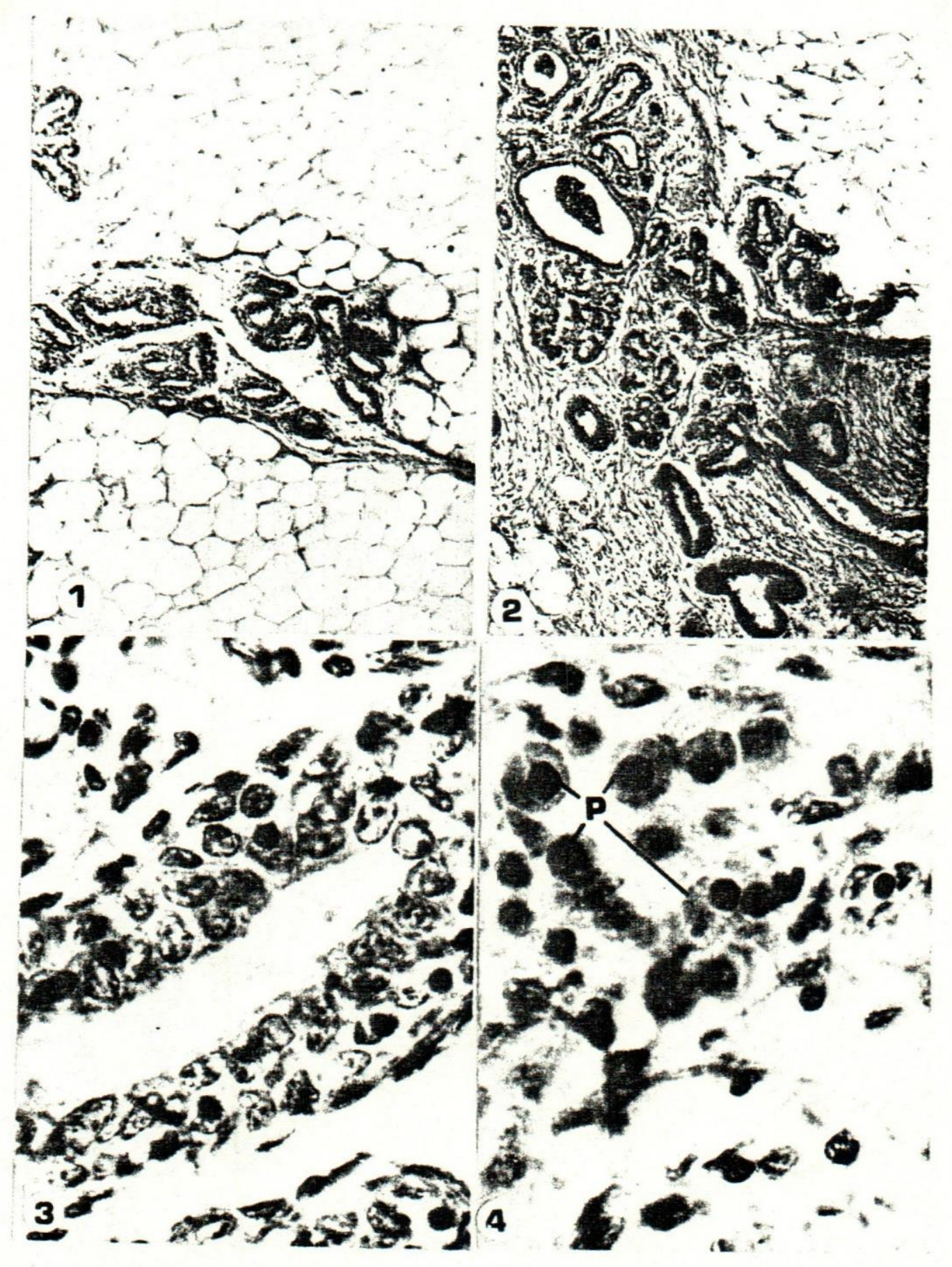

Fig. 1. Mammary gland of non pregnant ewe characterized by a group of ductules and abundant fat tissue. (Hx. and E. X 63).

Fig. 2. Mammary gland at 30 days of pregnancy characterized by small alveoli and large stomal area. (Hx. and E. X 63).

Fig. 3. A duct from mammary gland at 30 days of pregnancy characterized by the presence of two cell layers. (Hx. and E. X 400).

Fig. 4. Intralobular C.T. from mammary gland at 30 days of pregnancy showingabundant plasma cells (p). (Hx. and E. X 1000). 
18

,

$\frac{123}{23}$

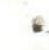




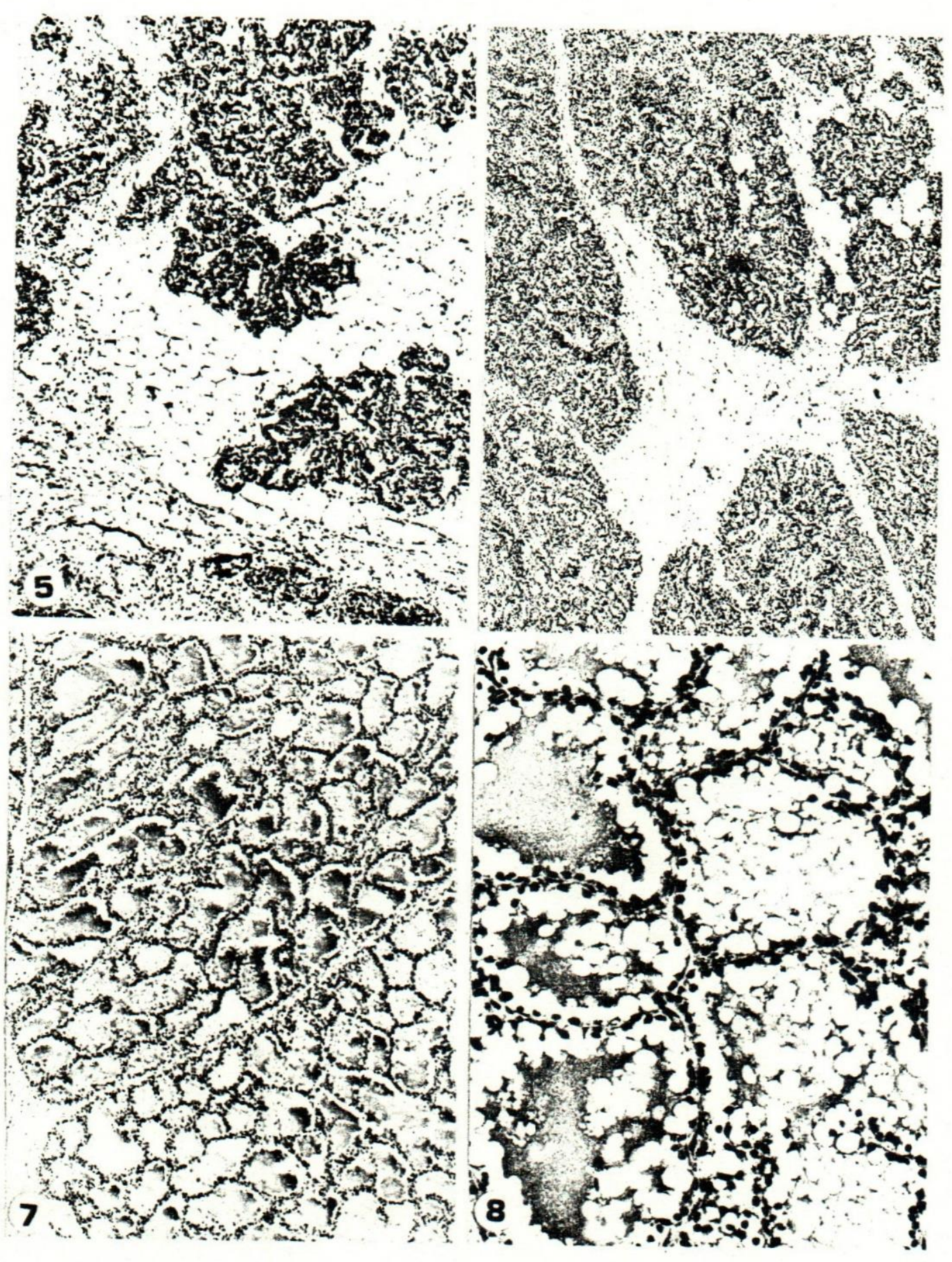

Fig. 5. Mammary g1 and at 90 days of pregnancy contain more developed glandular tissue. (Hx. and E. 63).

Fig. 6. Mammary gland at 120 days of pregnancy showed reduction in the stromal area. (Hx. and E. X 63).

Fig. 7. Mammary gland at 140 days of pregnancy contain we 11 developed milk alveoli filled with secretion. (Hx. and E. X 63).

Fig. 8. Milk alveoli at 140 days of pregnancy. Notice the large vacuoles in the secretory cells. (Hx. and E. X 63). 


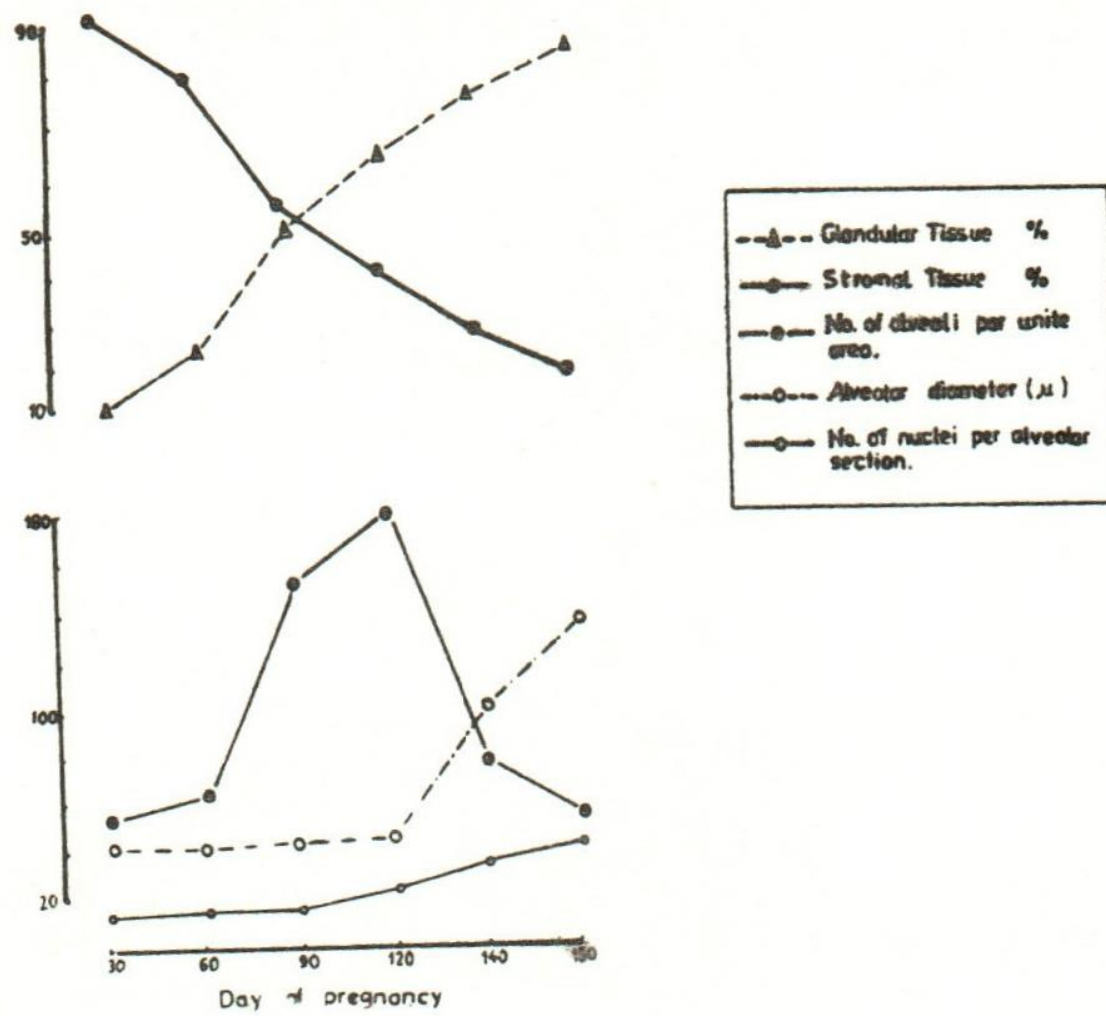

Fig. 9. Changes in estimates of mammary gland structure in ewe during pregnancy.

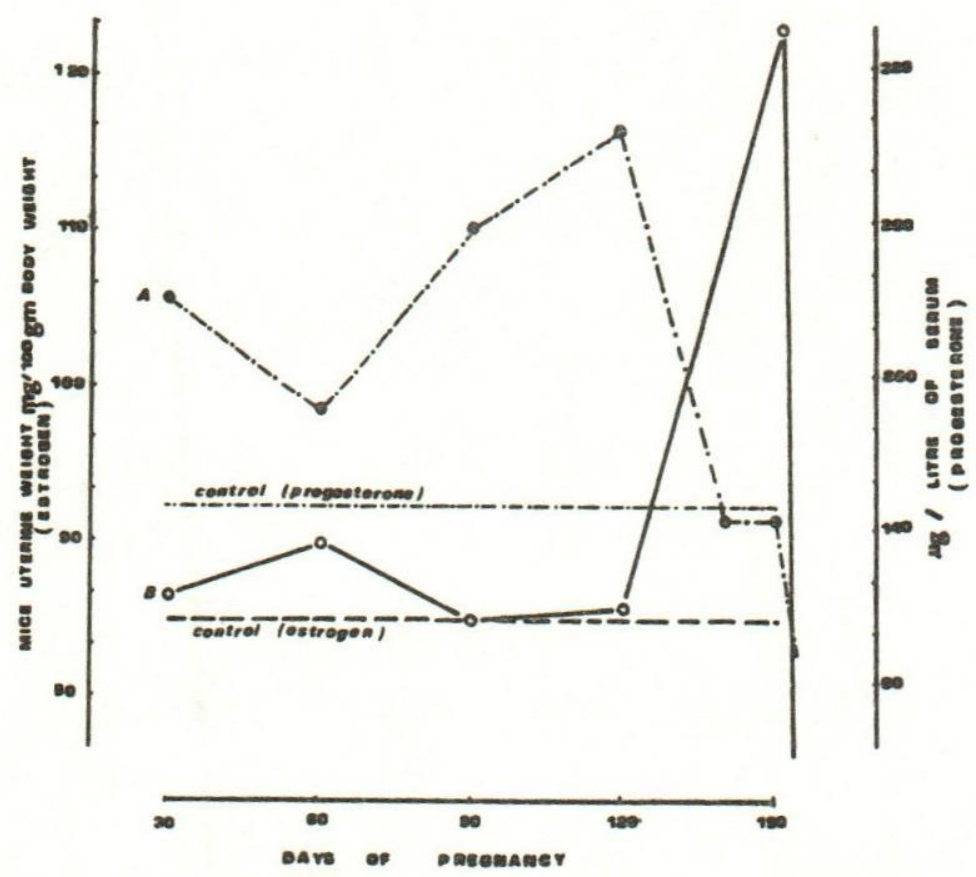

Fig. 10. Blood levels of estrogen (B) and proge sterone (A) in pregnant ewe. 
